\title{
Az eurázsiai hód (Castor fiber) táplálkozási és fásszárú-használati szokásaival kapcsolatos helyi tudás két évtizeddel a visszatelepítések kezdete után a Kárpát-medencében
}

\author{
Juhász Erika ${ }^{1}$, Babai Dániel ${ }^{2}$, Biró Marianna ${ }^{3}$, Molnár Zsolt ${ }^{3}$ és \\ Ulicsni Viktor ${ }^{1}$ \\ ${ }^{1}$ Szegedi Tudományegyetem, Ökológiai Tanszék, \\ 6726, Szeged, Közép fasor 52. \\ ${ }^{2}$ MTA Bölcsészettudományi Kutatóközpont Néprajztudományi Intézet, \\ 1097 Budapest, Tóth Kálmán utca 4. B épület, 8. emelet. \\ ${ }^{3}$ MTA Ökológiai Kutatóközpont, Ökológiai és Botanikai Intézet, \\ 2163 Vácrátót, Alkotmány u. 2-4. \\ e-mail:juhasz.erika43@gmail.com
}

\begin{abstract}
Összefoglaló: Az eurázsiai hód táplálkozásával és a fásszárú fajok hódok általi használatával kapcsolatos helyi ökológiai tudást a Kárpát-medence három tájában, a Kászoni-medencében (Románia), a Szigetközben és a Mura mentén (Magyarország) strukturált interjúk segítségével vizsgáltuk. A táplálkozási szokásokat, az életmódot, illetve a kidöntött vagy megrágott fásszárú fajokat illetően számos megfigyelés, adat gyűlt össze. Az összegyüjtött információk gyakran pontosak, máskor viszont nem egyeznek a tudomány álláspontjával. A helyiek szerint a hódok legtöbbször az adott területen uralkodó fásszárúakat használják, melyek Kászonban a Salix fragilis és az Alnus incana, a Szigetközben és a Mura-mentén a Salix alba és a Populus spp. Olykor preferencia-különbségekröl is említést tettek. Több Mura menti adatközlő említett kukoricaszárból épült hódvárakat. A helyi lakosság tapasztalatai értékes információkkal gazdagíthatják a tudományos eredményeket, ugyanakkor a természetvédelemmel kapcsolatos kommunikáció során érdemes figyelembe venni a tudományostól eltérő helyi véleményeket.
\end{abstract}

Kulcsszavak: táplálék-preferencia, helyi ökológiai tudás, természetvédelem, hódkár, Kászoni-medence, Szigetköz, Mura mente

\section{Bevezetés}

Az eurázsiai hód (Castor fiber, L. 1758) az 1990-es években megkezdett visszatelepítések és a spontán kolonizáció eredményeképpen újra megjelent a Kárpát- 
medencében (Halley \& Rossel 2002, Haarberg 2007, Bajomi 2011). Tevékenységével, különösen a hódkárral érintett területeken a helyi emberek figyelmének középpontjába került. Mivel a faj a 19. század közepén kipusztult Európa legtöbb országából, így Magyarországról is (Brehm, n. d., Nolet \& Rossel 1998), a jelenleg regisztrálható helyi tudás a generációról generációra átadott hagyományos tudás helyett döntően tapasztalati úton szerzett, saját megfigyelésekből álló, valamint szóbeszéd útján terjedő vagy a média által közvetített információkból áll.

Magyarországon a gazdasági erdőkben történő fadöntés az eurázsiai hóddal kapcsolatos konfliktusok legfontosabb forrása, de problémát jelenthet az üregásás is, elsősorban a csatornaparti utak alatt, vagy nagyon keskeny hullámterü folyók esetén a töltések oldalában (Czabán 2016). Hajózható folyóink mentén a hajózási út vízbe döntött fák általi szükítése, ún. ,akadók” képzése is konfliktust okoz (a szerzők személyes megfigyelése, 2017). A mezőgazdasági területek hódgátak okozta elárasztása szintén negatív attitüd kialakulásához vezethet a helyi gazdálkodók részéről (Young et al. 2007).

Az eurázsiai hód kizárólag növényevő, vízhez kötött életmódot folytató rágcsáló (Stocker 1985, Bozsér 2001) Tevékenységére erős befolyást gyakorolnak a hidrológiai és táplálékkínálati viszonyok: a közeli rokon észak-amerikai eredetű kanadai hóddal (Castor canadensis, Kuhl 1820) ellentétben az eurázsiai hódok gátakat többnyire csak meglehetősen sekély, keskeny vízfolyások mentén építenek (Hartman \& Törnlöv 2006). A gátépítéssel járó elárasztás által mindkét hódfaj indirekt és a táplálkozás révén direkt befolyást gyakorol a makrofita növényzetre (Law et al. 2014). Fás- és lágyszárú fajokból álló étrendjük a kiegészítő tápanyagok iránti igény és a felhalmozódó toxikus másodlagos anyagcseretermékek elkerülése miatt igen változatos (Belovsky 1984, Doucet \& Fryxell 1993, Ganzhom \& Harthun 2000), továbbá szezonális eltéréseket mutat. A nyári hónapokban föleg lágyszárúakat fogyasztanak, jelentősen befolyásolva ezzel a vízi növények biomasszáját (Parker et al. 2007). Összel és télen a zöld növényzet hiányában a fásszárúak fogyasztása jelentős (Jenkins 1979). Az őszi-téli táplálékot adó fakéreg, háncs, fiatal hajtás sokszor a fák kidöntése által válik elérhetővé (Bozsér 2001).

A füz- és nyárfajok (Salix és Populus spp.) kiemelten fontosak a hódok étrendjében, de további fásszárú fajok is preferáltak lehetnek (Fustec et al. 2001, O'Conell et al. 2008). A füzek és nyárak jelenléte az élőhelyválasztást is meghatározza (Fustec et al. 2001). A hódok előnyben részesítik a bokorfüzeseket, valamint a füz-nyár ligeterdőket, szemben egyéb, fás társulástípusokkal (pl. keményfás ligeterdők, gyertyános-tölgyesek, kőris- és égerligetek), valamint a fátlan és urbánus területekkel (John \& Kostkan 2009). 
Kutatásunkban a kászoni, szigetközi és Mura menti települések helyi lakosainak ökológiai tudását, tapasztalatait tárjuk fel a hódok táplálkozási szokásaival és a hódok által használt fásszárú fajokkal kapcsolatban. A jelen cikkben bemutatott helyi tudásanyagot a hazai, publikált táplálékpreferencia-vizsgálatok (Bozsér 2001, Czabán 2003, Právics 2012, Varjú \& Jánoska 2015) és saját terepi megfigyeléseink tükrében tárgyaljuk.

\section{Módszerek}

\section{Vizsgált területek}

Az eurázsiai hód táplálkozásával és fásszárú-használatával kapcsolatos helyi ökológiai tudás vizsgálatát a Kárpát-medence három tájában, a Kászoni-medencében (Románia), a Szigetközben és a Mura mentén (Magyarország) végeztük.

Kászonban a települések határát szántók és elsősorban a patakok mentén kisparcellás kaszálók jellemzik. A településtől és a patakoktól távoli hegyi kaszálók jelentős részét az elmúlt évtizedekben felhagyták, ezeken pionír erdőállományok jelentek meg (Betula bendula Roth 1788, Populus tremula L. 1753, Salix caprea L. 1753). Ezzel párhuzamosan a településhez közelebb fekvő, részben patakmenti kaszálóterületek művelése egyre nagyobb jelentőséget kap. A tájat behálózó kisebb vízhozamú patakok jelentik a hódok számára élőhelyet kínáló víztesteket, melyeket a hódok gátak segítségével duzzasztanak föl. A patakok mentén füz-éger ligetek jellemzőek. Az uralkodó füzfaj a törékeny füz (Salix fragilis L. 1753), az égerek többsége hamvas éger (Alnus incana (L.) Moench 1794, helyi nevén sima eger), de a mézgás éger (Alnus glutinosa (L.) Gaertn. 1791, helyi nevén fekete eger) is elöfordul. A bokorfüzek közül a part mentén a csigolyafüz (Salix purpurea L. 1753) a legjellemzőbb, melyet a helyiek sokszor kosárfüzként említenek. Itt közvetlenül a víz mellett föleg kaszálók találhatóak, az innen gyüjtött széna pedig nagy jelentőséggel bír a helyi gazdálkodás szempontjából.

A Szigetközi Tájvédelmi Körzet vízparti területeit az erdőgazdálkodás és az ármentesített területeken végzett szántóföldi gazdálkodás mellett elsősorban rekreációs célokkal (horgászás, evezés) keresik fel a helyiek. A Szigetközt a Duna élő mellékágai és holtágai hálózzák be, a táj egészét a víz alakította. Hidrológiáját és vegetációját jelentősen megváltoztatták a 19. századi folyószabályozások és a Bős-nagymarosi vízlépcső létrehozása a 20. század végén (Hahn et al. 2011).

A Szigetköz ártereinek alacsonyabban fekvő területein füz-nyár ligeterdők és nemesnyár-ültetvények váltogatják egymást. Az őshonos puhafafajok közül a legjellemzőbbek a fehér füz (Salix alba L. 1753) és a csigolyafüz, a fekete és a szürke nyár (Populus nigra L. 1753 és Populus x canescens (Aiton) Sm. 1804), az ide- 
genhonos fajok közül pedig a nemesnyár (Populus x canadensis Moench 1785), a fehér akác (Robinia pseudoacacia L. 1753), a mirigyes bálványfa (Ailanthus altissima (Mill.) Swingle 1916), a zöld juhar (Acer negundo L. 1753) és az amerikai kőris (Fraxinus pennsylvanica Marshall 1785) (Hahn et al. 2011). A partszegélyen a mézgás éger szórványosan jelenik meg. A magasabb térszíneket tölgykőris-szil ligeterdők uralják. A hódok által veszélyeztetett fő gazdasági érték a fa (nyersanyag), mely elsősorban nemesnyár. A szigetközi és hansági keskeny csatornák fásszárú-kínálata tapasztalataink szerint igen változatos. A bokorfüzes területektől a telepített akácosokon át a becserjésedett, cseresznyeszilva (Prunus cerasifera Ehrh.1789) és kökény (Prunus spinosa L. 1753) uralta keskeny parti sávig számos élőhelytípussal találkozhatunk, melyek a hódok tevékenysége szempontjából meghatározóak lehetnek. Hódok általi gátépítést kizárólag a csatornák esetében tapasztalhatunk, a folyókon nem.

A Mura mentén fekvő települések gazdálkodását a terület határmenti státusza befolyásolta. Az 1950-es években, a határ ellenőrzésének szigorodásával a Mura árterében található nagy kiterjedésű kaszálók mủvelése szinte lehetetlenné vált, ezek helyét mára nagy kiterjedésü, egykorú puhafaligetek foglalták el (Bódis et al. 2008). A rendszerváltást követően a legeltetéses állattartás gyakorlatilag teljesen megszünt (adataink szerint egy juhtartó gazda él Murarátkán). A növénytermesztést a nagytáblás szántóföldi mủvelés jellemzi, fontos termény a kukorica. A több hektáros hullámtéri szántók gyakran egészen a vízpartig lenyúlnak.

A hódok által lakott vizes élöhelyek zöme a Mura-menti Tájvédelmi Körzet része, nehezen áthatolható, többnyire csak horgászok által látogatott ártéri terület. A nagy kiterjedésủ puhafás állományokban elsősorban a füzfajok (Salix alba, $S$. fragilis), valamint kisebb mértékben a nyárak (fehér nyár - Populus alba L. 1753 és fekete nyár) jelentik a táplálékkínálatot. A Murán tavasszal és nyáron gyakori az áradás, amikor az Alpokban hóolvadás történik. Az időszakos ár a folyó kanyargó medrét folyamatosan alakítja, új zátonyokat, partszakaszokat, szigeteket, holtágakat hoz létre (Fehér é.n., Engi et al. 2012).

A hódok lakóhelye mindhárom tájban lehet partoldalba vájt üreg vagy faágakból, esetleg más növényi részek felhasználásával létrehozott hódvár.

Mindhárom tájban jellemző, hogy visszatelepített állományok terjedésével, és nem közvetlen a vizsgált területekre történő telepítéssel jelent meg a faj. A Kászonba 2009 körül érkezett egyedek az 1998 és 2001 között az Olt, a Maros és a Ialomiţa folyó mentén összesen elengedett 91 példánytól származnak (Ionescu et al. é.n.); Szigetközben 1985-86-ban bukkantak az ausztriai Duna-szakaszba telepített állományból lejutó egyedek nyomaira (Bajomi 2011); a Mura mentén pedig az 1997-ben a határhoz közeli horvát Dráva-szakaszba elengedett 29 példány 
(Bozsér 2007) közül már a telepítés évében megjelentek egyedek (Lelkes András, személyes közlés, 2015).

Vizsgálatunk a következő településekre terjedt ki: a Kászoni-medencében Kászonfeltíz, Kászonaltíz, Kászonújfalu, Kászonimpér, Jakabfalva; a Szigetközben Dunasziget, Kisbodak, Ásványráró; a Mura mentén Kerkaszentkirály, Muraszemenye és Murarátka.

A Kászoni-medence vizsgált településein 3033 lakos él, ebböl 2760 magyar nemzetiségü (http1). Becslésünk szerint a térség népességének számottevő hányada (60\%) kisparaszti gazdálkodásból él. A Mura mentén Muraszemenye, Kerkaszentkirály és Murarátka településeken összesen 1129 fő él, döntő többségük magyar nemzetiségü. A foglalkoztatottak aránya 27 és 35\% között változik (KSH 2013), a mezőgazdaságból élők aránya becslésünk alapján 15\%. A Szigetközben Dunaszigetről került ki az adatközlők döntő többsége. A település lakossága 1459 fö, többségében magyar nemzetiségü (KSH 2013). A település lakosságának 45\%a foglalkoztatott (KSH 2013), a mezőgazdaságból élők aránya mára elenyésző.

\section{Vizsgálati módszer}

Az adatgyüjtés Kászonban 2014-ben, a Szigetközben 2015-ben, a Mura mentén 2015-2016-ban folyt. Minden tájban az adatközlők fele (15 fó) véletlenszerüen került kiválasztásra, a másik fele (szintén 15 fó) a falvak lakosai szerint az átlagosnál nagyobb tudással, és a hódról kiterjedt ismeretekkel bíró emberek, ún. helyi szakértők közül került ki. Megjegyezzük, hogy a véletlenszerüen kiválasztott adatközlők között is voltak nagy tudásúak. A helyi tudás legmagasabb szintjét a nagy tudású adatközlők képviselik, akik kiválasztása először a közösségvezetők (polgármester, tanárok) javaslatai alapján, a továbbiakban hólabda-módszer segítségével történt. Ezen emberek között nagyobb arányban jellemző az aktív tájhasználat, főként mezőgazdasági munkák, illetve horgászás, gyermekek esetében fürdőzés, természetjárás. Az esetek jelentős részében a szakértő adatközlő ajánlása a hódok tevékenységével kapcsolatos személyes tapasztalatok miatt történt. A random adatközlők összesített tudása a helyi lakosság jellemző tudásanyagát reprezentálja. Ezek az adatközlők azon emberek közül kerültek ki, akiket a települések utcáin, boltjaiban, közösségi helyein mások ajánlása nélkül, véletlenszerüen szólítottunk meg, és akikkel egyeztetés után interjút készítettünk. A 90 adatközlő átlagéletkora 51 év (Kászon: 45, Szigetköz: 54, Mura mente: 55 év).

Az információgyüjtés fő módja strukturált szobai interjúk készítése volt (összesen 84 óra 42 percnyi felvétel készült, az interjúk átlagos hossza 46 perc - Kászon: 48, Szigetköz: 53, Mura mente: 45 perc), melyek többségét az interjúalany megkérdezése után diktafonra rögzítettük. A strukturált interjúk egy előre meghatározott kérdéssor mentén szerveződtek, de tartalmaztak szabad felsoroláson alapuló 
(free listing) kérdéseket is. A strukturált interjú adatlapjának előre megírt kérdései segítették az interjú készítőjét abban, hogy minden kérdést feltegyen valamennyi interjúalanynak (kvantitatív rész). Az interjúk free listing részében a beszélgetés alapját nyílt kérdések adták, amelyek kijelölték a beszélgetés irányát, egyúttal biztosították a lehetőséget a válaszadók számára, hogy gondolataikat, véleményüket is elmondhassák a beszélgetés során (kvalitatív rész) (lásd még Newing et al. 2011).

Az értékelés a következő kérdésekre adott válaszok alapján történt: [Mit eszik a hód?], ha az adatközlő szerint fásszárú fajokat eszik: [A fának melyik részét eszi?], [Milyen fákat használ a hód?], [Eszik-e a hód terményt vagy szénafüvet?], [Milyen hatással van a hód a halállományra?], [Mi alapján lehet következtetni a hódok jelenlétére?]. A kérdésekre kapott válaszokat - például a fafajok említését kvantifikáltuk, gyakoriság alapján táblázatba rendeztük (vö. Newing et al. 2011), és az adatokat szalagdiagramokkal ábrázoltuk. A későbbiek folyamán az idézetekben szereplő kapcsos-zárójelekben az interjú készítője által feltett kérdés vagy a megértést segítő kiegészítés szerepel. Az anonimitás megőrzése érdekében az interjúalanyokat kódnevekkel láttuk el a következő módon: 1. karakter: helyszín (K - Kászoni-medence, SZ- Szigetköz, M - Mura mente), 2. karakter: E (expert, azaz szakértő), vagy R (random), 3. karakter: sorszám (mely nem egyezik meg a köszönetnyilvánítás felsorolásának sorrendjével), pl.: KE1 - kászoni szakértő adatközlö 1 .

\section{Eredmények}

A legtöbb szigetközi és Mura menti megkérdezett, valamint a kászoni adatközlők fele evidenciaként kezeli, hogy a hód növényevő állat (1. ábra). A fák valamely részét táplálékként ismerők leggyakrabban a fa kérge, háncsa (,fa héja”); rügye, levele; továbbá fiatal hajtása, vékony ága kategóriákat említették: ,,a vékony sarjadékot, meg a vékony fát azt elhordja. Tehát ezeket a nagy fákat, ezt leboritja, vizen lekérgezi, legallyazza ..." (ME1). A szigetköziek több mint fele hangsúlyozta a csemeték fogyasztását: „, a vizparti sort teljesen kirágja. Tehát a csemetésbe nyilván nagyobb kárt tud csinálni, mer' hogy kisebb fát könnyebben kirág, de azt látom, hogy egész nagy fákat körberág” (SZE1).

A kászoni adatközlők közel fele gondolja azt, hogy a hódok a növényi táplálék mellett halat is esznek, vagy kizárólag hallal táplálkoznak, ritkábban gerinctelen állatokat említenek lehetséges zsákmányként. Gyakran vélekednek úgy, hogy a hódok gátépítési tevékenysége a halak számára megfelelő élőhely megteremtését vagy a halak visszatartását szolgálja. A Szigetközben és a Mura mentén is akad 


\section{Kászon - szakértő adatközlők}

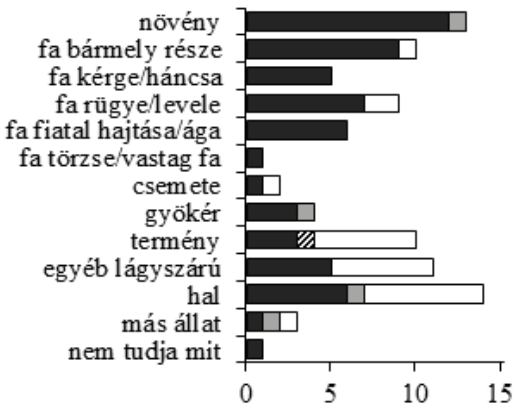

\section{Kászon - random adatközlők}

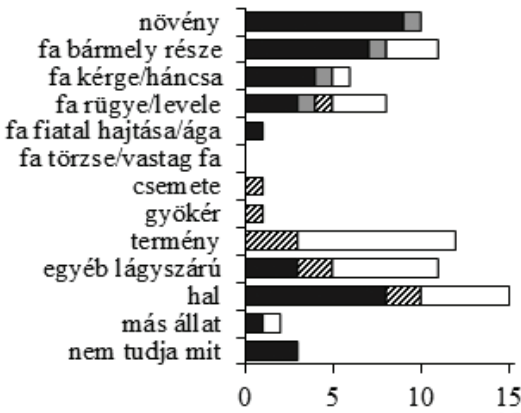

Eeszik

口talán eszik

anem tudja

口nem eszik

Az interjúalanyok általi emlitések száma

$\mathrm{Az}$ interjúalanyok általi emlitések száma

\section{Szigetköz-szakértő adatközlők}

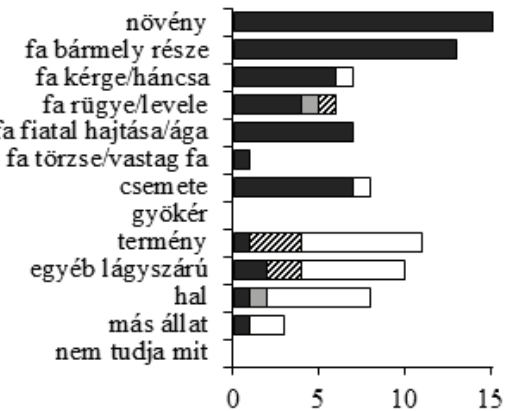

$\mathrm{Az}$ interjúalanyok általi emlitések száma

\section{Szigetköz-random adatközlők}

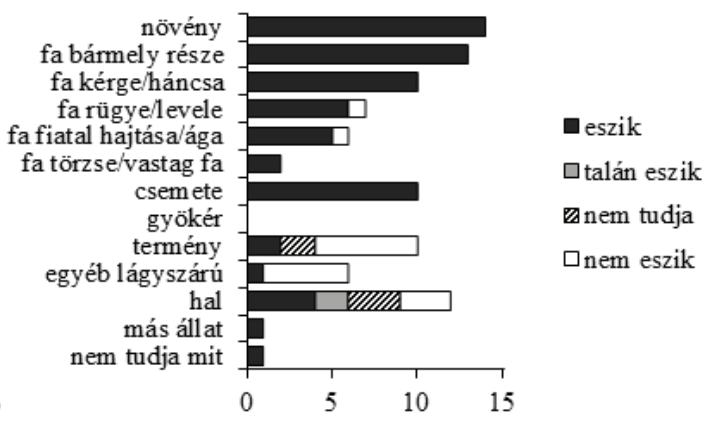

Az interjúalanyok általi emlitések száma

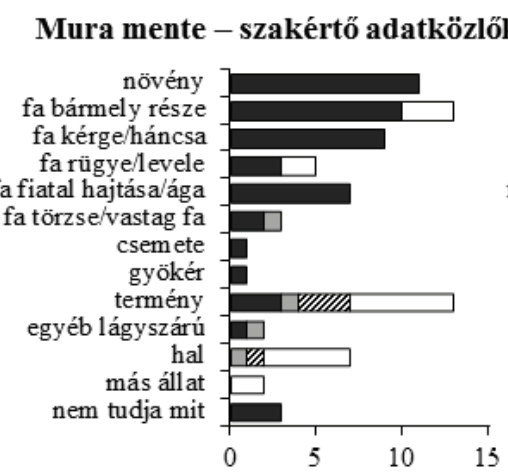

$\mathrm{Az}$ interjúalanyok általi emlitések száma

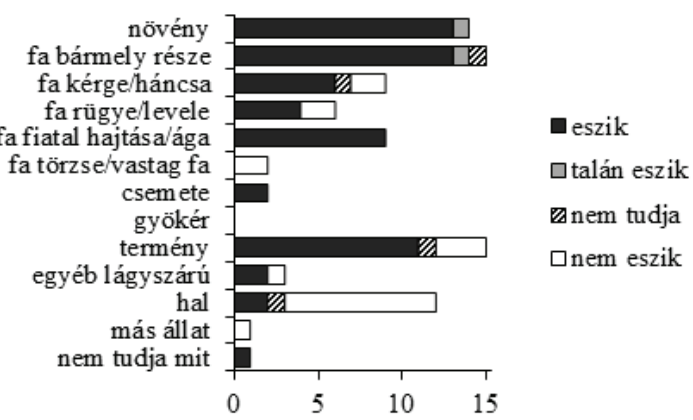

$\mathrm{Az}$ interjúalanyok általi emlitések száma

1. ábra. A hódok táplálkozásával kapcsolatos helyi tudás összegzése szakértő adatközlők és random adatközlők szerinti bontásban. 
néhány példa állati eredetű táplálék említésére: ,, [A halakat megeszi a hód?] Szerintem meg. Akkor mér' menne a vizbe?" (MR1). A Szigetközben egy szakértő adatközlő szerint csigákat, kagylókat, egy random szerint rovarokat is fogyaszt a hód, de a Mura mentén is felmerült az állati eredetü táplálék fogyasztása: , bizzunk benne, nem olyan, mint a nyest. Hát a nyest az télen, tehát a hideg idöbe ragadozó, amikor már kijön a jó idö, akkor meg növényevö" (ME2), azonban ez a Mura mentén alig jellemzö: „hát halállományt a vidra veszélyezteti csak. Hódnak semmi köze hozzá." (ME3)

A hód halállományra gyakorolt hatását vizsgáló kérdésre a Szigetközben számos esetben nem a halfogyasztás határozott tagadásával, hanem egyéb ökológiai hatások említésével válaszolnak: ,különbözö keszegfélék, küszök, azok biztos behúzódnak [a kidöntött fák ágai alá]. (...) Nagyobbaknak meg olyan szempontból lehet érdekes, hogy mondjuk egy-egy harcsafészek egy-egy ilyen fatörzs alatt simán elöfordulhat" (SZE2).

Egyes adatközlők a hódot tévesen állati eredetü táplálékot vagy kizárólag lágyszárú növényeket fogyasztó emlősként határozzák meg, ugyanakkor sok esetben ezek az emberek is átfogó ismeretekkel rendelkeznek a megrágott vagy kidöntött fásszárú fajokról, csupán ezt mással magyarázzák: ,,szerintem ezzel a rágással csak koptatja a fogait. Játszik vele. Láttam több alkalommal, hogy egy ággal ott elszórakozott” (ME4), vagy egyszerúen nem ismerik a tevékenység okát: ,, ez a vágás, amit, mert a fát lerágják, az milyen ösztön hajcsa arra reá. Az élelem, vagy ez egy hobbija. Ezt nem lehet tudni" (KE1).

A 2. ábra az egyes fásszárú nemzetségek hódok általi hasznosításával kapcsolatos helyi tudást mutatja be. A hasznosítás független attól, hogy az adatközlők mit emeltek ki a fadöntés, vagy megrágás okaként. A hasznosítás tehát a táplálkozást, a gátak és várak építését, a fogak faragás általi koptatását egyaránt jelentheti.

Kászonban a törékeny füz és a hamvas éger használatát hangsúlyozták a legtöbben: ,, [Melyik fát dönti ki?] Föleg az egerfa, füzfa. Hát a patakok mellett itt ezek vannak. Ez a ketto"' (KE2). Három adatközlő az éger füzzel szembeni, hat pedig a füz égerrel szembeni preferenciájáról beszélt: „,[És az égert?] Azt nem. Valami olyan anyagot tartalmaz, hogy azt annyira nem báncsák” (KE3). A kászoniak a füzfajok közt megkülönböztetik a bokorfüzeket: a csigolyafüz, a rekettyefüz (Salix cinerea L. 1753) és a kecskefüz (Salix caprea L. 1753, helyi nevén rakottya) taxonokat. A csigolyafüzet gyakran megemlítették a hódok által használt fásszárúak között. Ritkábban a közönséges nyír (Betula pendula Roth 1788), a rezgő nyár (Populus tremula L. 1753), a közönséges mogyoró (Corylus avellana L. 1753), de akár a lucfenyő (Picea abies (L.) H.Karst. 1881) használatáról is beszéltek. 

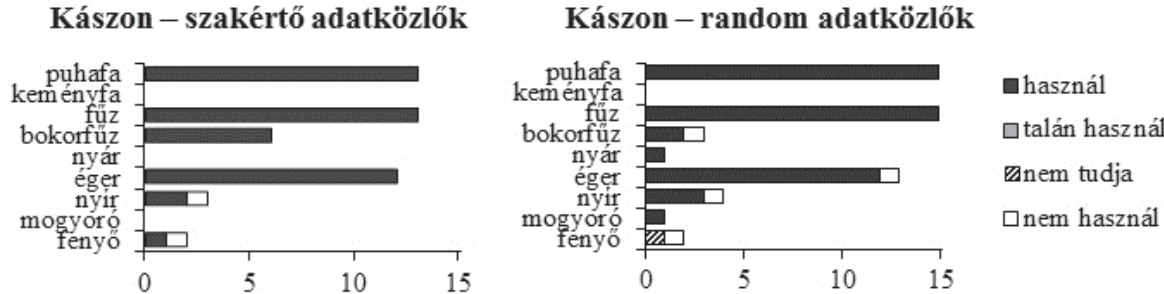

$\mathrm{Az}$ interjúalanyok általi emlitések száma

$\mathrm{Az}$ interjúalanyok általi emlitések száma

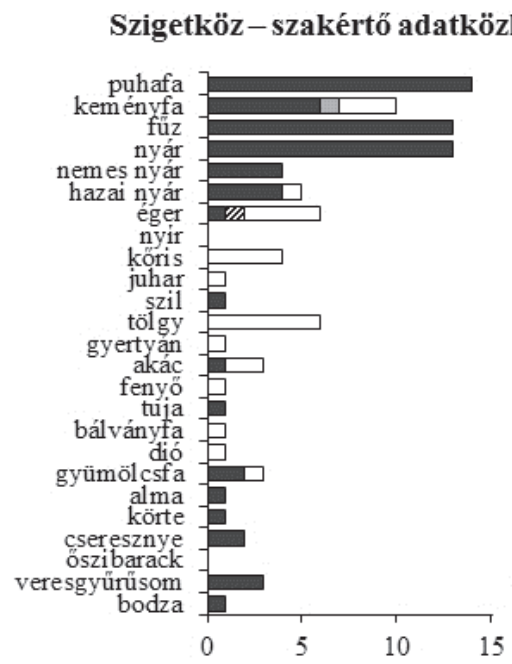

Szigetköz-random adatközlők

Az interjúalanyok általi emlitések száma

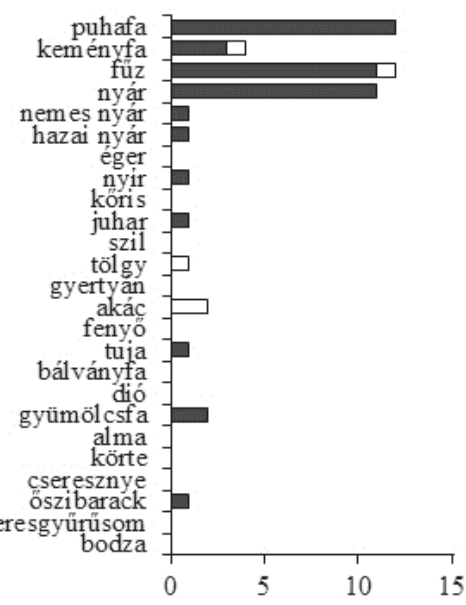

๑használ

口talán használ

ஐnem tudja

口nem használ

$\mathrm{Az}$ interjúalanyok általi emlitések száma
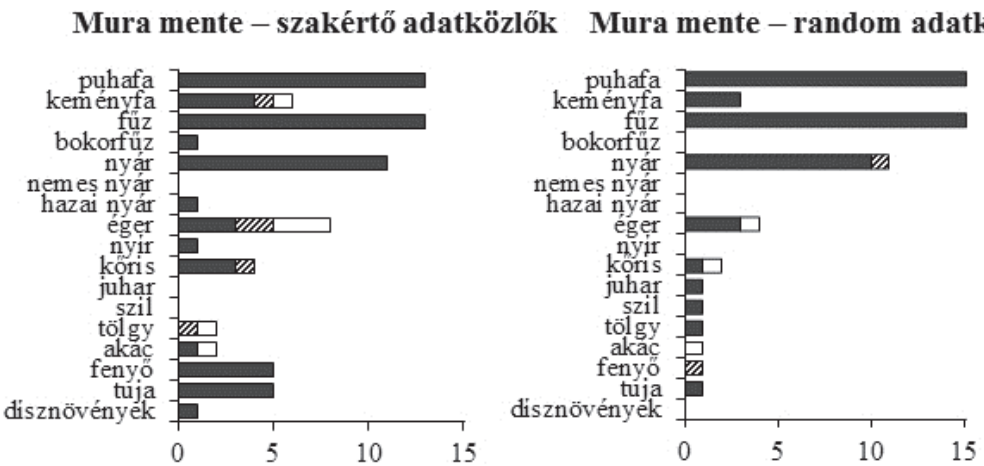

Qhasznál

$\square$ talán használ

Vnem tudja

$\square$ nem használ

Az interjúalanyok általi emlitések száma

Az interjúalanyok általi emlitések száma

2. ábra. Az egyes fásszárú nemzetségek hódok általi hasznosításával kapcsolatos helyi tudás összegzése szakértő adatközlök és random adatközlők szerinti bontásban. A használat jelentése: táplálkozás, gátépítés, várépítés és a fogak koptatása. 
A Szigetközben föként a fehér füz (Salix alba L. 1753) és a nyárfajok (Populus spp.) használatát említették. Három adatközlő szerint a füz preferált a nyárral szemben, egy szerint a nyár a füzzel szemben, két szakértő adatközlő véleménye pedig az, hogy a nemes nyár jelenti a hód legkedveltebb táplálékát: ,, az úgynevezett puha fákon belül is például a szürke nyárat, azt nem szereti, mer'annak nagyon rücskös a héja, és ugyanakkor a nemes nyárat, mer'kezdetbe nagyon vékony héja van, és gyors növekedése, kikereste, és azokat kidöntögette" (SZE3). Négyen állították azt, hogy a hód egyáltalán nem használ keményfát, kilencen azonban említést tettek valamely keményfa rágásáról [szil (Ulmus spp.), juhar (Acer spp.), akác, gyümölcsfák]. Keményfa-preferenciáról senki sem beszélt. Egy adatközlő említette a bálványfa kérgének megkezdését, ami kóstolásnak minősül, nem pedig használatnak. Egyes szigetközi adatközlők figyelmet fordítottak a cserjeszintre is, három szakértő adatközlő szerint szerepel a vörösgyürü-som (Cornus sanguinea L. 1753) a hódok által használt fásszárú fajok listáján.

A Mura mentén elsősorban a fehér füz, másodsorban a nyárfajok használatát emelték ki a helyiek, néhány esetben a keményfák kidöntéséről, megrágásáról is beszéltek. Öt megkérdezett tartotta preferáltnak a füzeket, egy pedig a nyárakat. Több adatközlő számolt be a fenyők, tuják, egyéb dísznövények hódok általi megrágásáról (horgásztanyákon), ami ellen helyenként villanypásztorral igyekeznek védekezni. „Akkor van az a fekvö tuja ott elöl. Azt nem kell nyírnom. Mer' azt szépen körbe eligazitja minden alkalommal" (ME1).

Termények, lágyszárúak táplálékként vagy építési alapanyagként való hasznosítását Kászonban és a Szigetközben kevesen említették (3. ábra). Kászonban nem a termények elfogyasztása, hanem inkább a mezőgazdasági területek hódgátak miatt bekövetkező elárasztása jelent problémát: ,, a hódnak az egyedüli bosszantó munkája ez. Hogy elönti, vízzel elönteti a földedet vagy a kaszálód” (KR1). A Mura mentén tizenhét adatközlő beszélt a kukoricatermény károsításáról, a kukoricaszár vár- vagy gátalapanyagként való hasznosításáról: , elrágták a szárát alul, behordták a vizbe, a fejet levették, azt gondolom, vitték a várba kajának, a kukoricaszárat meg beépitették a várba" (ME5). Többek szerint a kukorica lerágásának kizárólagos célja az építkezés: „[Terményben csinál kárt?] Kukoricatáblába'. Amelyik föleg a holtág mellett van, folyó mellett. Elhordja a hódvárba. Úgyhogy a termést megenni én nem láttam még. Mer' ugyanúgy rajta vannak a kukoricafejek" (MR2). A kászoniak és a szigetköziek szerint a hódvárak többnyire vékony ágakból, sárból épülnek, de egy kukoricából épült hódvárat Szigetközben is említettek. A Mura mentén élők szerint a hódok olykor más lágyszárú növényeket is beépítenek a várba: , azt mondják, olyan hogy összehord mindent. Zsombékot, nádat, meg mit tudom, abból csinál telepet" (MR1). , [Miböl épitették a gátat?] Hát, az érdekes dolog volt. Kukoricaszár. Meg iszap. Vízinövények. Amit talált itt fát" 


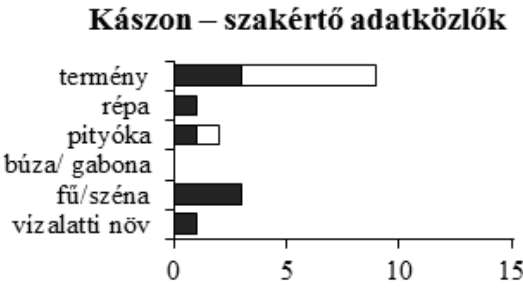

$\mathrm{Az}$ interjúalanyok általi emlitések száma

\section{Kászon - random adatközlők}

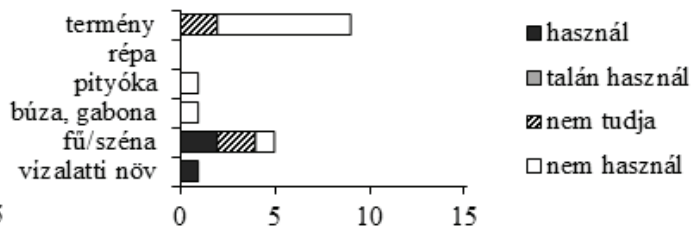

Az interjúalanyok általi emlitések száma

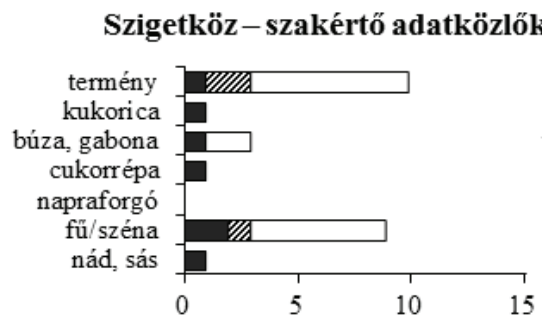

Az interjúalanyok általi emlitések száma

\section{Szigetköz-random adatközlők}

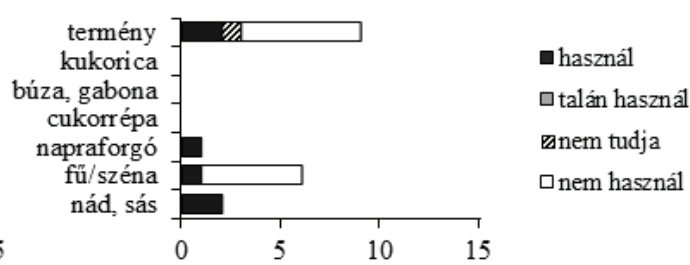

Az interjúalanyok általi emlitések száma

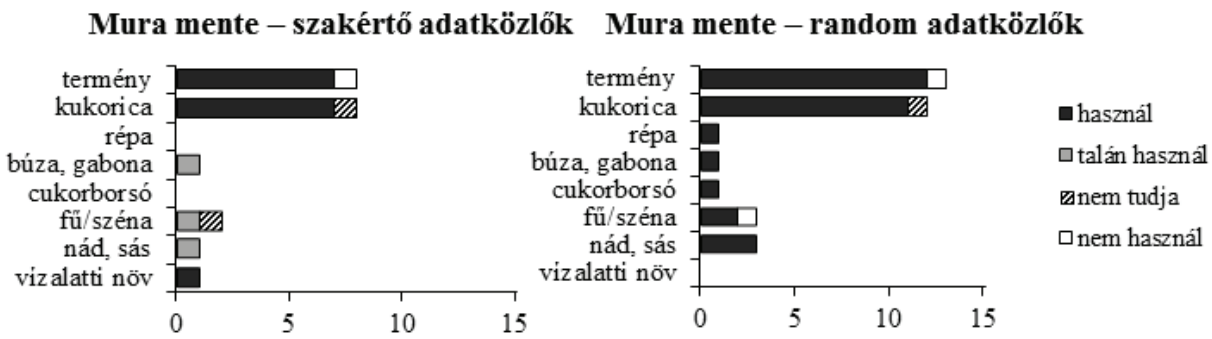

Az interjúalanyok általi emlitések száma

Az interjúalanyok általi emlitések száma

3. ábra. A lágyszárúak hódok általi hasznosításával kapcsolatos helyi tudás összegzése szakértő adatközlők és random adatközlök szerinti bontásban. A használat jelentése: táplálkozás, gátépítés és várépítés.

(ME6). Egyes adatközlők kiemelték a hódok táplálkozási szokásainak szezonális különbségeit: ,, ilyen lágyszárúakat is eszik gondolom, mer'ilyenkor nyáron nincs sok friss kár. A legtöbb kár az télen van, mikor nincs más” (SZE4). Akik szerint a hód a terményen kívül más lágyszárúakat is fogyaszt, azok vagy a szénafüvet vagy moszatot, víz alatti növényt, vagy sást, nádat neveztek meg táplálékként. „Növényevö. Biztos. Én úgy tudom, hogy a vegetációs idöszakba' sok mindent eszik. Nád, sásnak a gyökereit, gyöktörzse, vagy nem tudom mije van a sásnak” (SZE1). 
Megállapíthatjuk, hogy a véletlenszerüen megszólított (random) és célzottan felkeresett, szakértő (expert) adatközlők tudása a hód életmódjával, táplálkozásával kapcsolatban várakozásainkkal ellentétben csak kis mértékben tér el egymástól. A random adatközlők közül többen vélekedtek úgy, hogy a hódok hallal is táplálkoznak. A [Mit eszik a hód?] kérdésre adott „nem tudom” válasz mindkét adatközlö-csoportban ritka volt, de gyakran tapasztaltunk bizonytalanságot, találgatást. A két csoport között inkább az a különbség, hogy a szakértők személyes tapasztalataik birtokában magabiztosabb tudással rendelkeznek. A random adatközlők elsősorban az adott közösség hóddal kapcsolatos narratíváiból (elbeszélt történeteiből) és a médiából tájékozódnak. Ennek következtében tudásuk kevéssé magabiztos, de nem tartalmaz számottevően több téves ismeretet.

Összességében elmondható, hogy míg a random és szakértő adatközlők által átadott információkban tájanként vizsgálva csekély különbség mutatkozik, addig a tájak közötti különbségek igen jelentősek.

\section{Értékelés}

A hódok táplálkozási szokásaival kapcsolatos helyi ökológiai tudás vizsgálata és a fajjal kapcsolatos konfliktusok szorosan összefonódó kérdések. A vizsgált három tájban ez a tudás és a konfliktusok markánsan különböznek a tájhasználat és az életmód jellegzetességei alapján. Kászonban, ahol a kisparaszti gazdálkodás jellemző, számos gazdálkodó személyes tapasztalattal bír a hódok tevékenységét illetően. A konfliktust elsősorban a gátépítésből adódó kaszáló-elárasztások okozzák. A Mura-mentén, ahol kevesen foglalkoznak mezőgazdasággal, a hódok életmódjával kapcsolatban elsősorban a horgászok rendelkeznek megfigyelésekkel. Szigetközben szintén nem a mezőgazdasági kártétel az elsődleges szempont, hanem leginkább a hullámtérbe telepített nyárasok nagyarányú kidöntése a konfliktusok legfontosabb forrása.

A hódok fásszárú-használatával kapcsolatos helyi tudás igen sok fajra terjed ki a vizsgált településeken. A Kászoni-medencében a hódok táplálkozásával kapcsolatos átfogó kutatás eddig nem történt. Tapasztalataink azt mutatják, hogy Kászonban, továbbá hasonló kínálati viszonyok mellett a Bakonyban, a Hódos-ér mentén mindkét uralkodó faj, a füz és az éger fogyasztása jellemző, de a nagyobb átmérőjü égertörzseken többnyire csak néhány fognyomot találhatunk. A kászoni adatközlők közül is sokan említették a füz preferálását füzből és égerből álló kínálat esetén.

Egyre több hódcsalád jelenik meg az üdülöövezetek, falvak, városok peremén vagy akár belsejében. A kerti fásszárúak (gyümölcsfák, tuják, dísznövények) ki- 
döntése, lemetszése elsősorban a Szigetközben jellemző, de a Mura mentén is tapasztalható.

A különböző égerfajok hasznosítása kapcsán a szakirodalmi adatok nem egyértelmüek. Egyes vizsgálatok szerint a füz- és nyárfajok mellett többek között a mézgás éger is lehet preferált (Nolet et al. 1994), míg más eredmények azt mutatják, hogy bár a hamvas éger jelentős táplálék, hasznosítása a kínálathoz viszonyítva csekély (Haarberg \& Rossel 2006).

A szigetközi és Mura menti adatközlők közül a legtöbben a hód tevékenysége kapcsán a hazai nagyobb folyóinkat kísérö puhafás ligeterdők és ültetvények tipikus fafajait, a nyár- és/vagy a füzfajokat hangsúlyozták. A nyár- és füzpreferencia Gemencen is jellemző, ahol a hódok a csigolyafüzet, a mandulalevelü füzet (Salix triandra L. 1753), a fehér füzet és a fehér nyárat részesítik előnyben (Bozsér 2001).

(2003) a Hanságban végzett vizsgálatában a füz- és nyárfajok voltak jelen a legnagyobb számban, ezeket megközelítően kínálatukkal arányos mértékben fogyasztották a hódok, a szerző szignifikáns preferenciát nem állapított meg. A Mosoni-Duna mentén teljesen elkerülték a közönséges nyír, a vénic szil (Ulmus laevis Pall.) és a fehér akác egyedeit, míg a rezgő nyár és a füzfajok preferáltnak bizonyultak a kocsányos tölggyel (Quercus robur L. 1753) és a magas kőrissel (Fraxinus excelsior L. 1753) szemben (Varjú \& Jánoska 2015). Egy területen a hód közönséges mogyoró és zselnicemeggy (Padus avium Mill. 1768) preferenciáját mutatták ki (Varjú \& Jánoska 2015).

A Szigetközben, valamint a Hanságban szerzett személyes tapasztalataink is azt mutatják, hogy ahol a füz- és nyárfajok jelen vannak, ott valamennyi territóriumban ezek jelentik a hód táplálékának döntő többségét. Továbbá a hódok változó mértékben fogyasztják a helyiek által is használt fajként említett mézgás égert, mezei szilt (Ulmus minor Mill.1768), vénic szilt, mezei juhart (Acer campestre L. $1753)$ és zöld juhart, vörösgyürü-somot, közönséges mogyorót; a nem használtnak tartott kőris- és tölgyfajokat (Fraxinus és Quercus spp.) és az interjúkban nem említett zselnicemeggyet, madárcseresznyét (Cerasus avium (L.) Moench 1794), cseresznyeszilvát, kökényt és gyalogakácot (Amorpha fruticosa L. 1753). A preferenciaviszonyok tisztázása további elemzést kíván. A fekete bodza (Sambucus nigra L. 1753) metszése nagyon ritkán fordul elö, elkerülését Czabán (2003) is leírta. A Szigetközben és a Hanságban a kiterjedt akácosok jelenléte ellenére fehér akác fogyasztását nem jegyeztük fel, de erre is akad magyarországi példa (Dóc, Percsorai-csatorna, a szerzők személyes megfigyelése, 2017). Az akácot egy szigetközi interjúalany sorolta a fogyasztott fajok közé.

A Mura mentén elsősorban a fehér és a törékeny füz, valamint a nyárfajok fogyasztása jelentős (a szerzők személyes megfigyelése, 2015, 2016), de a szil- és 
kőrisfajok, a kocsányos tölgy, a vadalma (Malus sylvestris (L.) Mill. 1768), a mézgás éger, a kökény, a vörösgyürü-som, a rekettyefüz, és a közönséges mogyoró is szerepel a tápláléklistán (Právics 2012). A helyiek a vadalmát, a kökényt, a somot és a mogyorót nem említették, de a felsoroltakon kívül a juhart és az akácot egyegy alkalommal igen.

Általánosságban elmondható, hogy a szakértő adatközlők ismeretei valamennyi helyszínen kissé pontosabbak, szélesebb körüek, a random adatközlők esetében gyakoribbak az állati eredetü táplálék fogyasztásával kapcsolatos tévhitek. Ezen tévhitek Kászonban való elterjedését magyarázhatja, hogy a hódok megjelenése elött néhány évvel a halak száma drasztikusan csökkenni kezdett az ottani vizekben: „mert a hal most nem sok van. Valamikor itt annyi, itt felfelé pisztráng, s mindenféle vót ezekbe a patakokba, de most meg vannak szünve azok is. Úgyhogy lehet, hogy azt ök mégeszik" (KE4). A halak eltünése mögött természetesen más okot kell feltételeznünk: , régebb több hal vót, de ugye a [patak] szabályozódott, s egyenesen megy, és nincs meg az a környezet a halaknak... Párhuzamosan, amikor a szabályozás történt, akkor kezdödött el a nagyobb kaliberü vegyszerezés és a sok vegyszer használata" (KE5). Annak ellenére, hogy a kászoniak egy része már a médiából is tájékozódik, a szóbeszéd szerepe még mindig erősen meghatározó a helyi tudás alakulásában. Erre utal, hogy a „,hallottam”, az „aszongyák” stb. kifejezések rendszeresen megjelennek az interjúkban. A hódok táplálkozásával kapcsolatos pontos és részletes megfigyelések mellett a hiedelmek is szájról szájra terjednek, és ezek is átadódnak a fiatalabb generációnak. 146 kászoni tanuló iskolai tudáspróbájából kiderül, hogy 56\%-uk úgy gondolja, a hód halat eszik (Horváth Annamária, biológiatanárnő szíves segítségével megvalósítva, 2014).

A hódok általi lágyszárú-fogyasztás témakörében a helyiek kevés fajszintü ismerettel rendelkeznek, vélhetően azért, mert a rejtett életmódot élő állat ezen tevékenységét nehéz megfigyelni, továbbá a vizes élőhelyek lágyszárú fajainak csekély a gazdasági jelentősége: „, hát az a helyzet, hogy itt ezen a vízparti környezetbe, itt a lágyszárú az nem érték. Olyan értelembe, hogy a gazdálkodás szempontjából. Egy kikaszálandó valami” (SZE3). A terményben okozott kár nagyságáról megoszlanak a vélemények. A kukorica szárának táplálkozást vagy egyéb célokat szolgáló összegyüjtését a Kárpát-medence számos más pontján is tapasztalhatjuk (a szerzők személyes megfigyelése 2014-2017).

A hódok táplálkozási szokásainak hazai és nemzetközi kutatási eredményei gyakran kisebb-nagyobb mértékben eltérnek egymástól, továbbá a helyi lakosok megfigyeléseitől. Úgy véljük, ezeknek az eltérések azon része, mely nem téves információkból vagy tudáshiányból származik a különböző táplálékkínálati és preferenciaviszonyokból fakad. Bizonyos fásszárú fajok együttes jelenléte, törzs- 
átmérő-kategóriáinak megoszlása más-más viselkedésforma kialakulását vonhatja maga után.

Az eurázsiai hód a Kárpát-medence faunájának egy olyan régi-új eleme, mely tevékenységével feltünést kelt, a helyi lakosság érdeklődését váltja ki. A hóddal kapcsolatos, néhány év vagy évtized alatt létrejött helyi tudás nem pusztán a hagyományos tudás kialakulásának, fejlődésének kezdetektől történő nyomon követését teszi lehetővé, hanem olyan fontos információkat is magában hordoz, melyeknek ökológiai, természetvédelmi relevanciájuk lehet. A helyiek ismeretei a hódok szembetünőbb szokásairól részletesebbek, ilyenek például a gazdasági jelentőségü vagy a lakosság számára esztétikai értéket képviselő törzsek kidöntése, valamint a gát- és várépítés.

Az eurázsiai hód életmódjának teljes körü, tudományos igényü vizsgálata azonban csak komplex, terepi adatgyüjtésen alapuló kutatással valósulhat meg. A fásszárúfogyasztás és a kínálat közötti összefüggések, a táplálék-preferencia feltárása egységes módszerrel végzett, átfogó, kárpát-medencei szintü, számos élőhelytípusra kiterjedő elemzést, hatásvizsgálatot igényel. A hódok folyókísérő erdőkre, faültetvényekre kifejtett ökológiai hatásának megértése hódkár-mérséklési alternatívák kidolgozásához is hozzásegíthet.

Az eurázsiai hód Európa-szerte lezajlott visszatelepítési programjai természetvédelmi szempontból szinte példátlan sikernek számítanak, de az egyre jelentósebb hódprobléma a gazdálkodókat hátrányosan érinti. A hód mára Magyarország valamennyi folyóján megjelent, és sok térségben a keskeny csatornákon is magas egyedsürüséget ért el. A Kárpát-medencén belül a hódok tevékenysége a Szigetközben és a Hanságban okozza a legtöbb problémát. A következő években Magyarország újabb területein várható a gazdasági kártétel súlyosbodása, a természetvédelem és a gazdálkodói oldal közötti konfliktus kiéleződése. További intézkedések is szükségessé válhatnak. Az élőhelyek telítődése, az egyedszám növekedése az állományszabályozás megkezdését, a gyérítési gyakorlat kidolgozását sürgeti (Czabán, 2016).

Habár a tájban élő emberek tudása számos érdekes és értékes elemet tartalmaz, bizonyos szempontból hiányos is, olykor pedig komoly tévhitekkel terhelt. A természetvédelmi szempontból is támogatható kármegelőzési módszerek hatékonysága sajnos sok esetben igen alacsony, de vannak olyan hibás döntések, melyek elkerülése lényeges lehet. Még most is rendszeresen találkozhatunk esetekkel, amikor a nemesnyárakat közvetlenül a csatornák partszegélyére ültetik, vagy a hódok által kidöntött fák ágrendszerét is elszállítják, ami a hódok számára fontos táplálékot jelentene, nélküle viszont az állatok újabb fák kidöntésére kényszerülnek. Lehetséges, hogy ezen gazdálkodói döntések egy része is a hódokkal kapcsolatos tudáshiányból fakad. 
Ezúton szeretnénk felhívni a figyelmet az ismeretterjesztő anyagok, a médián keresztüli kommunikáció fontosságára, ami nem csak a tévhitek eloszlatását, hanem a hódkár-megelőzési lehetőségek megismertetését is segítheti. Ez a kommunikáció azonban nem lehet egyoldalú. A hódkárok nagyságát, mibenlétét az érintetteknél, tehát a helyieknél pontosabban senki sem ismerheti. A természetvédelem és a helyi lakosság közötti párbeszédnek kölcsönös tudásáramláson érdemes alapulnia.

Köszönetnyilvánítás - Köszönetet mondunk adatközlöinknek: Balázs B., Balázs N., Balázsi A., Bartha I., Bodó M., Borbáth A., Borbáth K., Csűrös R., Gál A., Horváth A., Illyés V., id. Karcsa A., Koszti I., Koszti J., Kotró Cs., Kővári Zs., László T., Makó E., Makó L., Mihácz J., Mihály S., Miklós A., Okos A., Posztuly L., Posztuly M., Ráduly M., Szökő J., Szűcs A., Tamás I., Tódorán A. (Kászoni-medence); Belovitz K., Besser S., Besser S-né, Cina F., Cseh D., Dán S., Földes E., Földes Z., Füzfa A., Glaser I., ifj Cina F., Kis S-né, Komlódi A., Koncz M, Lancz E-né, Légrádi R., Lévai E., Majtényi J., Majtényi J-né, Molnár J., Molnár K., Németh B., Németh T., Palotás Zs., Papp L., Platzer G., Stenczinger M., Stenczinger I., Stenczinger M., Takács I. (Szigetköz); Andor B., Bagladi G-né, Bánfai J., Bekő B., Birkás J., Bíró Z., Faragó L., Fülöp J., Honcz R., Horváth A., Horváth I., Kaiser T., Káli J., Kertész G. J., Kovács Á., Nagy I., Nagy J., Simon I., Simon N., Soós F., Stropka J., Strupka Z., Süle J., Szabó I., Tamás R., Varga B., Varga I., Varga J., Varga Z. (Mura mente). Köszönjük Albert Krisztiánnak az interjúk elkészítésében való részvételét, Füzfa Zoltánnak és családjának szigetközi gyüjtésünk támogatását, Horváth Annamáriának pedig köszönjük, hogy rendelkezésünkre bocsátotta a kászoni gyerekek tudáspróbájának anyagát. A szigetközi és hansági tapasztalatok gyűjtésében nyújtott segítségért Czabán Dávidnak tartozunk köszönettel. Juhász Erika munkáját az Új Nemzeti Kiválóság Program, Babai Dániel munkáját az MTA Bolyai János Kutatási Ösztöndíja, Biró Marianna munkáját részben „A fenntartható természetvédelem megalapozása magyarországi Natura 2000 területeken" címü svájci-magyar együttmüködési projekt (SH/4/8) támogatta. „Az Emberi Erőforrások Minisztériuma ÚNKP-16-2 kódszámú Új Nemzeti Kiválóság Programjának támogatásával készült"

\section{Irodalomjegyzék}

Bajomi, B. (2011): Reintroduction of the Eurasian beaver (Castor fiber). - Hungary. Danube Parks Network of Protected Areas, Directorate of Duna-Dráva National Park, Budapest, Hungary, 26 p.

Belovsky, G. E. (1984): Summer diet optimization by beaver. - Am. Midl. Nat. 111: 209-222. doi: http://dx.doi.org/10.2307/2425316

Brehm, A. (n. d.): Hód (Castor fiber). - In: Brehm, A. (szerk.): Az állatok világa egy kötetben (reprint, 1989). - Állami Könyvterjesztő Vállalat, Maecenas Könyvkiadó, Budapest, pp. 560-570.

Bódis J., Fehér Cs. E., Lelkes A. \& Szeglet P. (2008): A Mura ártér élővilága. Élöhelyek a Kerka torkolatától Letenyéig. - Interreg III A Közösségi Kezdeményezés Szlovénia-MagyarországHorvátország Szomszédsági Program („Ember, Mura, Természet”). 132 p. 
Bozsér, O. (2001): Hódok az óvilágban. - WWF Magyarország, Budapest, 28 p.

Bozsér, O. (2007): Amit a hódról tudni érdemes. - WWF füzetek 26. WWF Magyarország, Budapest.

Czabán, D. (2003): A Hanságba visszatelepitett hódok (Castor fiber) élöhely-és táplálékválasztási szokásai. - MSc diplomadolgozat, Eötvös Loránd Tudományegyetem, Budapest, 71 p.

Czabán, D. (2016): Hódok a Szigetközben. - In: Korda, M. (szerk.): Az erdőgazdálkodás hatása az erdők biológiai sokféleségére. - Tanulmánygyüjtemény, pp. 403-418.

Doucet, C. M. \& Fryxell, J. M. (1993): The effect of nutritional quality on forage preference by beavers. - Oikos 67: 201-208. doi: http://dx.doi.org/10.2307/3545464

Engi Zs., Tóth G., Steinmann, F. \& Braun, M. (2012): Historical morphological reconstruction of the Mura river (SW of the Carpathian basin) by using GIS methods. - Z. Geomorphol. 56: 63-77. doi: http://doi.org/10.1127/0372-8854/2012/S-00091

Fehér E. (szerk.) (é. n.): Tájváltozás a Mura mentén. Tájtörténeti tanulmány. - Interreg III A Közösségi Kezdeményezés Szlovénia-Magyarország-Horvátország Szomszédsági Program („Ember, Mura, Természet"). 59 p.

Fustec, J., Lodé, T., Le Jacques, D. \& Cormier, J. P. (2001): Colonization, riparian habitat selection and home range size in a reintroduced population of European beavers in the Loire. - Freshwater Biol. 46: 1361-1371. doi: http://dx.doi.org/10.1046/j.1365-2427.2001.00756.x

Ganzhorn, J. U. \& Harthun, M. (2000): Food selection by beavers (Castor fiber albicus) in relation to plant chemicals and possible effects of flooding on food quality. - J. Zool. 251: 391-398. doi: http://dx.doi.org/10.1111/j.1469-7998.2000.tb01090.x

Haarberg, O. \& Rosell, F. (2006): Selective foraging on woody plant species by the Eurasian beaver (Castor fiber) in Telemark, Norway. - J. Zool. 270: 201-208. doi: http://dx.doi.org/10.1111/ j.1469-7998.2006.00142.x

Haarberg, O. (2007): Amit a hódról tudni érdemes. Az eurázsiai hód Magyarországon - visszatelepítés, védelem és állományszabályozás. - WWF Magyarország, Budapest, $16 \mathrm{p}$.

Hahn, I., Gergely, A. \& Barabás, S. (2011): Changes in the active floodplain vegetation of the Szigetköz. - Annali di Botanica 1: 1-8. doi: http://dx.doi.org/10.4462/annbotrm-9117

Halley, D. J. \& Rosell, F. (2002): The beaver's reconquest of Eurasia: status, population development and management of a conservation success. - Mammal Rev. 32: 153-178. doi: http:// dx.doi.org/10.1046/j.1365-2907.2002.00106.x

Hartman, G. \& Törnlöv, S. (2006): Influence of watercourse depth and width on dam building behaviour by Eurasian beaver (Castor fiber). - J. Zool. 268: 127-131. doi: http://dx.doi. org/10.1111/j.1469-7998.2005.00025.x

Ionescu, G., Popa, M., Paşca, C., Sīrbu, G., Scurtu, M., Visan, D. \& Jurj, R. (é.n.): Support for reintroduced beaver population in Romania. - Final report. The Rufford Small Grants Foundation - Carpathians Foundation, Brasov, Románia, 9 p.

Jenkins, S. H. (1979): Seasonal and year-to-year differences in food selection by beavers. - Oecologia 44: 112-116. doi: http://dx.doi.org/10.1007/BF00346408

KSH - Központi Statisztikai Hivatal (2013): 2011. évi népszámlálás, 3. - Területi adatok, 3.8. Győr-Moson-Sopron megye. Györ, 274 p. elérhetö: http://www.ksh.hu/docs/hun/xftp/idoszaki/ nepsz2011/nepsz_03_08_2011.pdf (Utolsó letöltés időpontja: 2017. május 31).

John, F. \& Kostkan, V. (2009): Compositional analysis and GPS/GIS for study of habitat selection by the European beaver, Castor fiber in the middle reaches of the Morava River. - Folia Zool. 58: $76-86$.

Law, A., Jones, K. C. \& Willby, N. J. (2014): Medium vs. short-term effects of herbivory by Eurasian beaver on aquatic vegetation. - Aquat. Bot. 116: 27-34. doi: http://doi.org/10.1016/j. aquabot.2014.01.004 
Newing, H., Eagle, C. M., Puri, R. K. \& Watson C.W. (2011): Conducting Research in Conservation. Social science methods and practice. - Routledge, Taylor \& Francis Group, London and New York, $376 \mathrm{p}$.

Nolet, B. A., Hoekstra, A. \& Ottenheim, M. M. (1994): Selective foraging on woody species by the beaver Castor fiber, and its impact on a riparian willow forest. - Biol. Conserv. 70: 117-128. doi: http://doi.org/10.1016/0006-3207(94)90279-8

Nolet, B. A., \& Rosell, F. (1998). Comeback of the beaver Castor fiber: an overview of old and new conservation problems. - Biol. Conserv. 83: 165-173. doi: http://doi.org/10.1016/S0006$\underline{3207(97) 00066-9}$

O'Connell, M. J., Atkinson, S. R., Gamez, K., Pickering, S. P., \& Dutton, J. S. (2008). Forage preferences of the European beaver Castor fiber: implications for re-introduction. - Conserv. Soc. 6: 190. doi: http://dx.doi.org/10.4103/0972-4923.49213

Parker, J. D., Caudill, C. C. \& Hay, M. E. (2007): Beaver herbivory on aquatic plants. - Oecologia 151: 616-625. doi: http://dx.doi.org/10.1007/s00442-006-0618-6

Právics, M. (2012): Az eurázsiai hód (Castor fiber) állományának és táplálkozásának vizsgálata a Kerka mentén. - Szakdolgozat, Nyugat-Magyarországi Egyetem.

Stocker, G. (1985): Biber (Castor fiber L.) in der Schweiz. Probleme der Wiedereinbürgerung aus biologischer und ökologischer Sicht. - Eidgenössische Anstalt für forstliches Versuchswesen, Birmensdorf. Bericht, Nr. 247, 149 p.

Varju, J. \& Jánoska, F. (2015): Az eurázsiai hód (Castor fiber Linnaeus, 1758) fás szárú táplálékpreferenciája és élöhelyhasználata a Mosoni-Dunán. - Erdészettudományi Közlem. 5: 129-144. doi: http://dx.doi.org/10.17164/EK.2015.009

Young, J., Richards, C., Fischer, A., Halada, L., Kull, T., Kuzniar, A., \& Watt, A. (2007): Conflicts between biodiversity conservation and human activities in the Central and Eastern European countries. - AMBIO 36: 545-550. doi: http://doi.org/10.1579/0044-7447(2007)36[545:CBBCA H]2.0.CO;2

\section{Internetes hivatkozások:}

http1: http://nepszamlalas.adatbank.transindex.ro/?pg=etnikai\&id=438. Utolsó letöltés idöpontja: 2017. május 31. 


\title{
Local ecological knowledge on feeding habits and woody plant species usage of the reintroduced Eurasian beaver (Castor fiber) in the Carpathian Basin two decades after its reintroduction
}

\author{
Erika Juhász ${ }^{1}$, Dániel Babai ${ }^{2}$, Marianna Biró ${ }^{3}$, Zsolt Molnár ${ }^{3}$ and \\ Viktor Ulicsni ${ }^{1}$ \\ ${ }^{1}$ University of Szeged, Department of Ecology, \\ H-6726 Szeged, Közép fasor 52, Hungary \\ ${ }^{2}$ MTA MTA Research Centre for The Humanities, Institute of Ethnology, \\ H-1097 Budapest, Tóth Kálmán utca 4. B épület, 8. emelet, Hungary \\ ${ }^{3}$ MTA Centre for Ecological Research, Institute of Ecology and Botany, \\ H-2163 Vácrátót, Alkotmány u. 2-4, Hungary \\ e-mail: juhasz.erika43@gmail.com
}

Local ecological knowledge of the nutrition of and the use of woody species by the Eurasian beaver (Castor fiber) was studied in three regions of the Carpathian Basin: Kászon Basin (Romania), Szigetköz and Mura River region (Hungary). Local understanding on alimentary habits, lifestyle and woody species usage were collected from 90 informants by structured interviews. In most cases locals possessed detailed knowledge on the issues studied. However, some data seemed to be unreliable or incorrect. According to local people, beavers generally used the dominant tree species of a given region. These were Salix fragilis and Alnus incana in the Kászon region, while Salix alba and Populus spp. in Szigetköz and in the Mura River region. Several informants living along the Mura River mentioned beaver dams built from corn-stalks. Our findings showed that experiences and observations of local people could improve scientific understanding of beaver behaviour. Furthermore, we argue that reciprocal knowledge exchange between local stakeholders and conservationists may help reduce human-beaver conflicts.

Keywords: táplálék-preferencia, helyi ökológiai tudás, természetvédelem, hódkár, Kászoni-medence, Szigetköz, Mura mente 